\title{
Anatomical and energy characteristics of charcoal made from five species
}

\author{
Silvana NISGOSKI ${ }^{*}$, Washington Luis Esteves MAGALHÃES², Francielli Rodrigues Ribeiro BATISTA², \\ Ramiro Faria FRANÇA³, Graciela Inés Bolzon de MUNIZZ \\ 1 Universidade Federal do Paraná, Departamento de Engenharia e Tecnologia Florestal, Av. Prefeito Lothário Meissner, 632 - Jardim Botânico - 80.210-170 - Curitiba - PR, Brazil. \\ 2 Embrapa Florestas. Estrada da Ribeira, km 111. Caixa Postal 319. 83.411-000 Colombo - PR, Brazil. \\ ${ }^{3}$ Universidade Federal do Paraná, Curso de Pós Graduação em Engenharia Florestal, Av. Prefeito Lothário Meissner, 632 - Jardim Botânico - 80.210-170 - Curitiba - PR, Brazil \\ * Corresponding author: silvana.ufpr@gmail.com
}

\section{ABSTRACT}

Charcoal is an important energy raw material and its properties are influenced by the wood's anatomical and chemical composition and the production process. The aim of this study was to evaluate the anatomical characteristics, calorific power and volatiles and ash content of carbonized wood from Byrsonima spicata, Calophyllum brasiliense, Cecropia sciadophylla, Cochlospermum orinocense and Schefflera morototoni. The calorific power varied from 26,878 to $31,117 \mathrm{~kJ} \mathrm{~kg}^{-1}$; the content of volatile materials ranged from 20.9 to $31.7 \%$; ash content ranged from 0.1 to $3.8 \%$; and carbon content varied from 68.2 to $75.3 \%$. Anatomical structures of charcoal can be used for species identification. The studied species are not indicated for charcoal production because the levels of ash and volatile compounds are higher than those recommended for charcoal produced for household use. In addition, the calorific power and level of carbon content are insufficient for use in the steel industry.

KEYWORDS: carbonization, carbonized wood properties, wood structure.

\section{Características anatômicas e energéticas do carvão de cinco espécies}

\section{RESUMO}

O carvão vegetal é um importante insumo energético, sendo suas propriedades influenciadas pela composição anatômica e química da madeira utilizada e pelo processo de produção. Esse trabalho teve como objetivo avaliar as características anatômicas, poder calorífico e o conteúdo de voláteis e cinzas da madeira carbonizada de Byrsonima spicata, Calophyllum brasiliense, Cecropia sciadophylla, Cochlospermum orinocense e Schefflera morototoni. O poder calorífico variou de 26.878 a $31.117 \mathrm{~kJ} \mathrm{~kg}^{-1}$; o teor de voláteis variou de 20,9 a 31,76\%; o teor de cinzas variou de 0,1 a 3,8\% e o teor de carbono no carvão ficou entre 68,2 e 75,3\%. A estrutura anatômica do carvão pode ser utilizada na identificação de espécies. As espécies estudadas não são indicadas para a produção de carvão, pois o teor de cinzas e materiais voláteis é superior ao indicado para carvão produzido para uso doméstico. Além disso, porque o poder calorífico e o teor de carbono do carvão são insuficientes para uso na indústria siderúrgica.

PALAVRAS-CHAVE: carbonização, propriedades do lenho carbonizado, estruturas da madeira. 


\section{INTRODUCTION}

Brazil is the world's largest producer and consumer of charcoal, mainly for the production of pig iron, steel and ferroalloys. About $50 \%$ of the wood consumed in the world annually is used for energy purposes (Moreira 2011). Because of the current global dependence on fossil fuels, it is necessary to find new energy sources that are less polluting and safer with regard to availability (Santos and Hatakeyama 2012).

Historically in Brazil, wood from native forests was the main raw material used to make charcoal, but today a combination of stricter environmental regulation and increased enforcement has increased the use of wood from planted forests, mainly eucalyptus, to make charcoal for industrial uses (Yazdani et al. 2012).

However, in certain regions, wood is still often carbonized from illegally cut trees. In such cases, enforcement of logging rules is hampered due to the difficulty of identifying the species, making it necessary to obtain more information on the intrinsic characteristics of carbonized wood to enable species identification. Previous studies (Lopes Pasquali et al. 2002; Kwon et al. 2009; Silva et al. 2007) have shown the influence of species and carbonization conditions on the properties of charcoal and the possibility of using anatomical characteristics for illegal trade control (Gonçalves et al. 2012; Muñiz et al. 2012).

In this context, it is important to analyze native species with commercial potential, particularly those growing in the Amazon region. The wood from Byrsonima spicata, Calophyllum brasiliense, Cecropia sciadophylla, Cochlospermum orinoccense and Schefflera morototoni is used to build small structures, to make furniture, wine barrels, boxes, interior finish items, musical instruments and paper, as well as to produce charcoal (Paula and Alves 2007). Therefore, the aim of this study was to provide information on the anatomical characteristics, calorific power and volatiles and ash content of carbonized wood of these five species, to contribute to efforts to differentiate species and control illegal trade, as well as to support possible use of sawmill residues of these woods for making charcoal, to reduce waste.

\section{MATERIALS AND METHODS}

The wood samples of the species Byrsonima spicata (Cav.) DC. (Malpighiaceae), Calophyllum brasiliense Cambess. (Calophyllaceae), Cecropia sciadophylla Mart. (Urticaceae), Cochlospermum orinocense (H.B.K.) Steud. (Cochlospermaceae), Schefflera morototoni (Aubl.) Decne. $\&$ Planch. (Araliaceae) came from the municipality of Nova Maringá, Mato Grosso state $\left(13^{\circ} 1^{\prime} 2^{\prime \prime} \mathrm{S}, 57^{\circ} 4^{\prime} 8^{\prime \prime} \mathrm{W}\right)$. The trees were cut in a natural forest, and disks were extracted from the diameter at breast height $(\mathrm{DBH})$, with thickness of about
$8 \mathrm{~cm}$. Eight samples were obtained of each species, with dimensions of $2 \times 2 \times 5 \mathrm{~cm}$, oriented in the three anatomical planes. Each sample was wrapped in aluminum foil and carbonized in a muffle furnace (Q318S, Quimis, São Paulo, Brazil), with a final temperature of $450{ }^{\circ} \mathrm{C}$ and a heating rate of $1.66{ }^{\circ} \mathrm{C} \mathrm{min}^{-1}$. The carbonized material remained at the final temperature for two hours.

The description of the anatomical elements of the charcoal samples followed the orientations of the International Association of Wood Anatomists (IAWA 1989), on the basis of 25 readings regarding frequency and tangential diameter of the vessels and height and width of the rays in micrometers. The images of the general distribution of the cells in the transversal plane were obtained with a stereomicroscope with digital camera (Zeiss Discovery V12, Carl Zeiss, Göttingen, Germany). For detailed analysis, the samples were manually broken and fixed with a conductive carbon double-sided tape into traditional scanning electron microscopy stubs. The images were obtained directly from the carbonized material, without coating, with a tabletop microscope (TM-1000, Hitachi, Tokyo, Japan). The cell dimensions of the wood and charcoal were compared by the Tukey test at probability of 5\% (Oliveira 2008).

A randomly selected portion of each charcoal sample was ground and sifted and the fraction retained between 40-60 mesh sieves was used for immediate chemical analysis, according to the NBR 8112 standard from the Brazilian Association of Technical Standards (ABNT 1983). The sample material was also used to measure the calorific power in an abiotic calorimetric pump (IKA 5000, Staufen, Germany), following the recommendations of NBR 8633 (ABNT 1984).

\section{RESULTS}

The porosity and vessel arrangement of the species was more distinct after carbonization. Irregular contraction of vessels and rupture of rays were observed in Byrsonima and Schefflera. Axial parenchyma bands in Calophyllum brasiliense and aliform parenchyma in Cecropia sciadophylla were not observed in carbonized wood. In Cochlospermum orinocense, the vessels were more visible in charcoal (Figure 1). The summary of the anatomical characteristics is as follows:

Growth rings distinct in Schefflera morototoni demarcated by difference in fiber walls, and indistinct in other studied species. Wood diffuse-porous; vessels solitary and in radial multiples of 2-4 present in Byrsonima spicata; vessels solitary and in radial multiples of 2-5 observed in Cecropia sciadophylla; vessels solitary, predominant, and occasional in radial multiples of 2-3 present in Calophyllum brasiliense, Cochlospermum orinoccense and Schefflera morototoni. Tyloses occasional present in Calophyllum (Figure 2A) and Cecropia; simple perforate plates (Figure 2B) and alternate intervessel 


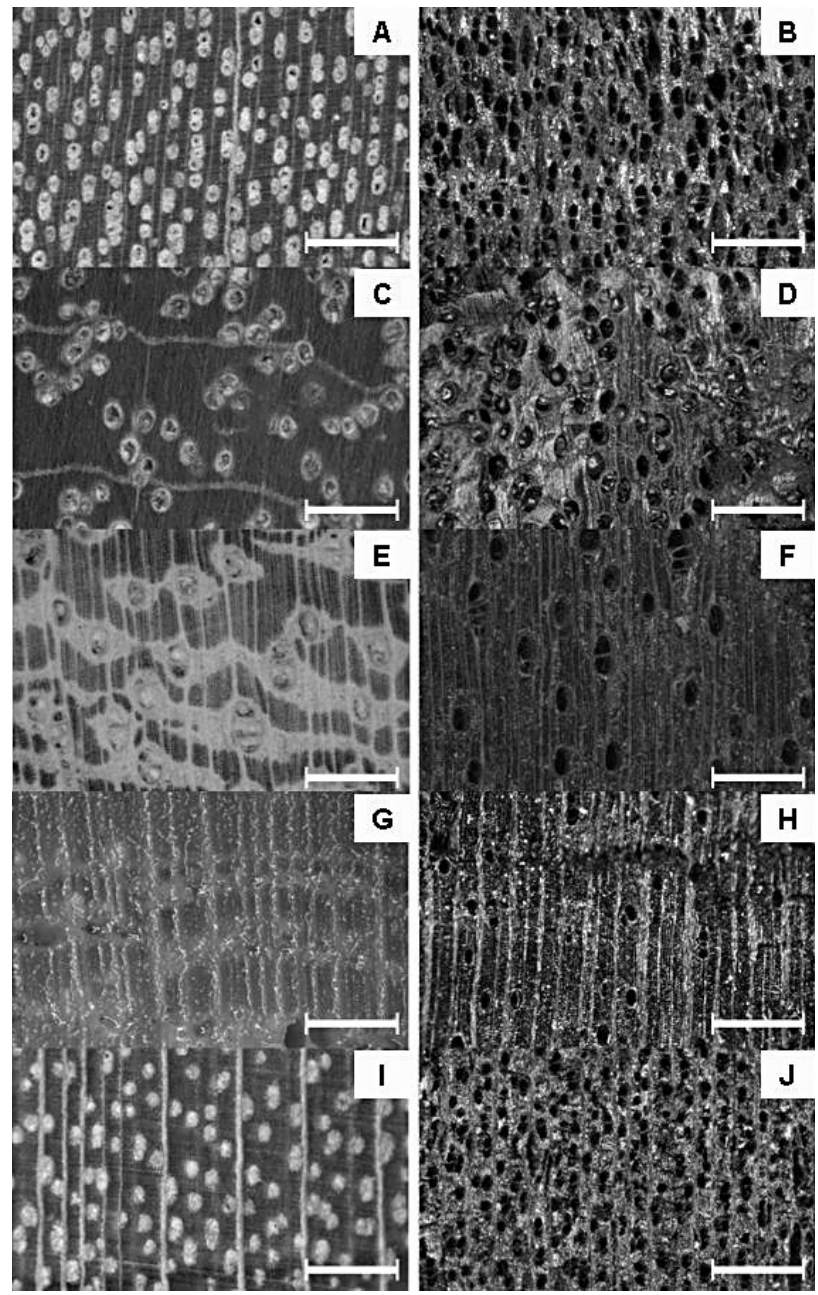

Figure 1. Byrsonima spicata wood (A) and charcoal (B); Calophyllum brasiliense wood (C) and charcoal (D); Cecropia sciadophylla wood (E) and charcoal $(\mathrm{F})$; Cochlospermum orinocense wood $(\mathrm{G})$ and charcoal $(\mathrm{H})$; Schefflera morototoni wood (I) and charcoal (J). Scale bar $=1 \mathrm{~mm}$.

pits (Figure 2C-D) observed in all species. Vessel-ray pitting and vessel-parenchyma pitting are similar to intervessel pits; coarse vessel-ray pits observed in Schefflera.

Axial parenchyma is scanty paratracheal (Byrsonima, Schefflera), in bands (Calophyllum), vasicentric, aliform, confluent and in narrow marginal bands (Cecropia), vasicentric and in bands (Cochlospermum). Heterogeneous rays observed in all species; Ray width is variable, uniseriate (Calophyllum), with 1-3 seriate (Byrsonima), 1-4 seriate (Cecropia), 1-6 seriate (Cochlospermum), 3-4 seriate (Schefflera), irregularly storied in Schefflera. Prismatic crystals are present in marginal ray cells in Byrsonima (Figure 2E). Thick to very thick fiber walls were observed in Byrsonima and Calophyllum, thin fiber wall present in Cecropia, Cochlospermum and Scheffera, septate fiber present in Schefflera.

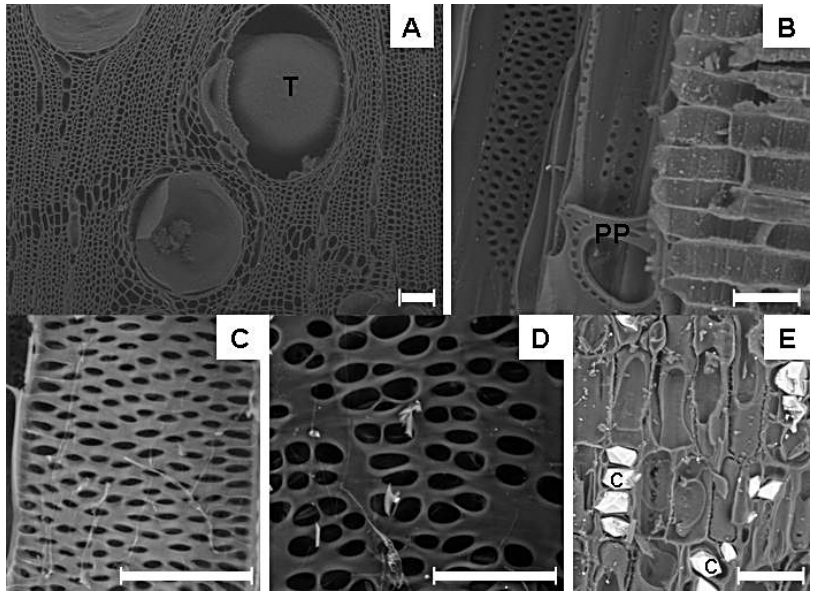

Figure 2. Transversal section of Calophyllum brasiliense charcoal (A); Radial section of Schefflera morototoni charcoal (B); Intervessel pits in Cochlospermum orinocense charcoal (C) and Cecropia sciadophylla charcoal (D); Crystals in Byrsonima spicata charcoal (E). T = tyloses; $\mathrm{PP}=$ perforation plate; $\mathrm{C}=$ crystal. Scale bar $=50 \mu \mathrm{m}$

The dimensional changes in the anatomical structures between wood and charcoal did not present a uniform pattern (Table 1). The tangential diameter of the vessels decreased significantly in Schefflera (28\%), Cecropia (29\%) and Byrsonima (39\%). The frequency of vessel increased in Byrsonima, Calophyllum and Schefflera. The ray width was the parameter that varied the least in terms of statistical significance, declining 22\% in Calophyllum and 31\% in Cochlospermum.

Byrsonima spicata and Calophyllum brasiliense were the species with the greatest number of dimensional variations in the characteristics analyzed between the wood and charcoal, with respective reductions of $36 \%$ and $17 \%$ in the frequency of rays and increases of $40 \%$ and $25 \%$ in the frequency of vessels. In Calophyllum brasiliense, only the tangential diameter of the vessels did not present a significant difference, in contrast to Cecropia sciadophylla, for which this was the only characteristic that diminished, due to the contraction of the wood during the carbonization process. Opposite behavior was observed in Cochlospermum orinocense, with a significant decline in the width and height of the rays, and Schefflera morototoni, in which there was no difference in ray dimensions.

Charcoal properties (Table 2) varied among species, calorific power from 26,878 to $31,117 \mathrm{~kJ} \mathrm{~kg}^{-1}$; volatile materials content from 20.9 to $31.7 \%$; ash content from 0.1 to $3.8 \%$; and fixed carbon from 68.2 to $75.3 \%$. Calophyllum brasiliense was the species with lowest content of ash and fixed carbon and highest volatiles content. Schefflera morototoni was the species with highest calorific power and content of fixed carbon. 
Table 1. Summary of changes in anatomical characteristics between wood (W) and charcoal (C). Data are given as mean and (standard deviation).

\begin{tabular}{|c|c|c|c|c|c|c|c|c|c|c|}
\hline \multirow[t]{2}{*}{ Species } & \multicolumn{2}{|c|}{ Vessel diameter $(\mu \mathrm{m})$} & \multicolumn{2}{|c|}{ Vessels $\mathrm{mm}^{-2}$} & \multicolumn{2}{|c|}{$\begin{array}{l}\text { Ray height } \\
(\mu \mathrm{m})\end{array}$} & \multicolumn{2}{|c|}{$\begin{array}{l}\text { Ray width } \\
(\mu \mathrm{m})\end{array}$} & \multicolumn{2}{|c|}{ Rays $\mathrm{mm}^{-1}$} \\
\hline & W & $\mathrm{C}$ & W & $\mathrm{C}$ & W & $\mathrm{C}$ & W & C & W & C \\
\hline Byrsonima spicata & $\begin{array}{l}154.0 \mathrm{a} \\
(16.8)\end{array}$ & $\begin{array}{l}94.4 \mathrm{~b} \\
(31.0)\end{array}$ & $\begin{array}{l}13.2 \mathrm{a} \\
(2.3)\end{array}$ & $\begin{array}{l}18.1 \mathrm{~b} \\
(2.0)\end{array}$ & $\begin{array}{l}771.6 \mathrm{a} \\
(277.4)\end{array}$ & $\begin{array}{l}460.9 \mathrm{~b} \\
(197.6)\end{array}$ & $\begin{array}{l}38.0 \mathrm{a} \\
(14.0)\end{array}$ & $\begin{array}{l}35.9 \mathrm{a} \\
(13.9)\end{array}$ & $\begin{array}{l}10.9 \mathrm{a} \\
(1.7)\end{array}$ & $\begin{array}{l}7.4 \mathrm{~b} \\
(1.1)\end{array}$ \\
\hline Calophyllum brasiliense & $\begin{array}{c}195.2 \mathrm{a} \\
(33.9)\end{array}$ & $\begin{array}{c}199.2 \mathrm{a} \\
(56.7)\end{array}$ & $\begin{array}{l}5.5 \mathrm{a} \\
(1.4)\end{array}$ & $\begin{array}{l}6.8 b \\
(2.3)\end{array}$ & $\begin{array}{c}187.8 \mathrm{a} \\
(51.3)\end{array}$ & $\begin{array}{c}136.5 b \\
(49.1)\end{array}$ & $\begin{array}{l}15.5 \mathrm{a} \\
(2.8)\end{array}$ & $\begin{array}{r}12.4 \mathrm{~b} \\
(2.9)\end{array}$ & $\begin{array}{l}6.4 \mathrm{a} \\
(1.5)\end{array}$ & $\begin{array}{l}5.3 \mathrm{~b} \\
(1.8)\end{array}$ \\
\hline Cecropia sciadophylla & $\begin{array}{c}258.1 \mathrm{a} \\
(48.6)\end{array}$ & $\begin{array}{l}182.7 \mathrm{~b} \\
(52.9)\end{array}$ & $\begin{array}{l}2.6 \mathrm{a} \\
(1.1)\end{array}$ & $\begin{array}{l}2.9 \mathrm{a} \\
(1.4)\end{array}$ & $\begin{array}{l}569.9 a \\
(249.9)\end{array}$ & $\begin{array}{l}496.4 a \\
(138.4)\end{array}$ & $\begin{array}{l}57.9 \mathrm{a} \\
(13.4)\end{array}$ & $\begin{array}{r}35.3 \mathrm{a} \\
(6.2)\end{array}$ & $\begin{array}{l}3.9 \mathrm{a} \\
(0.8)\end{array}$ & 4.2a (1.5) \\
\hline $\begin{array}{l}\text { Cochlospermum } \\
\text { orinocense }\end{array}$ & $\begin{array}{l}130.0 \mathrm{a} \\
(26.9)\end{array}$ & $\begin{array}{l}114.7 a \\
(29.0)\end{array}$ & $\begin{array}{l}2.3 \mathrm{a} \\
(1.2)\end{array}$ & $\begin{array}{l}3.0 \mathrm{a} \\
(1.6)\end{array}$ & $\begin{array}{l}923.6 \mathrm{a} \\
(275.0)\end{array}$ & $\begin{array}{l}550.8 b \\
(326.2)\end{array}$ & $\begin{array}{l}99.2 \mathrm{a} \\
(23.1)\end{array}$ & $\begin{array}{l}67.8 \mathrm{~b} \\
(36.9)\end{array}$ & $\begin{array}{l}5.1 a \\
(0.8)\end{array}$ & 4.6a (1.5) \\
\hline Schefflera morototoni & $\begin{array}{c}147.2 \mathrm{a} \\
(23.0)\end{array}$ & $\begin{array}{l}104.8 \mathrm{~b} \\
(22.0)\end{array}$ & $\begin{array}{l}11.0 \mathrm{a} \\
(2.2)\end{array}$ & $\begin{array}{l}14.0 \mathrm{~b} \\
(3.3)\end{array}$ & $\begin{array}{l}576.8 \mathrm{a} \\
(155.5)\end{array}$ & $\begin{array}{l}691.6 \mathrm{a} \\
(302.3)\end{array}$ & $\begin{array}{l}76.0 \mathrm{a} \\
(9.1)\end{array}$ & $\begin{array}{l}72.2 \mathrm{a} \\
(20.8)\end{array}$ & $\begin{array}{l}2.6 \mathrm{a} \\
(0.6)\end{array}$ & $3.6 b(1.1)$ \\
\hline
\end{tabular}

*Means followed by the same letter in each specie characteristic, do not differ from wood and charcoal by the Tukey test at probability of $5 \%$.

\section{DISCUSSION}

In Calophyllum brasiliense and Cecropia sciadophylla, the opposite structure changes can be explained by the difference in the quantity and distribution of the axial parenchyma cells, wall thickness of the fibers and width of the rays, since Calophyllum presents narrow parenchyma bands, medium to thick fiber walls and uniseriate rays, unlike Cecropia, which has vasicentric parenchyma, thin wall fibers and from 2 to 4 multiple rays. Observing the wood anatomical structures, Schefflera morototoni has septate fibers and irregular ray stratification, characteristics absent in Cochlospermum orinocense, besides few parenchyma cells, resulting in statistically significant dimensional variations in opposite characteristics.

The influence of the fiber wall thickness, axial parenchyma cell quantity and distribution and ray width has also been noted by Prior and Gasson (1993), Kim and Hanna (2006), Kwon et al. (2009), among others, in reports of variations in function of the carbonization process of various species. An increase in the tangential diameter after carbonization at $400{ }^{\circ} \mathrm{C}$ of Acacia tortilis, Ziziphus mucronata and Sclerocarya caffra (Prior and Gasson 1993), and reduction in tangential diameter of the vessels in species from the cerrado (savannah) region of São Paulo (Gonçalves et al. 2012), were related to species and production process. A significant increase in the frequency of vessels in Cedrelinga catenaeformis and Enterolobium schomburgkii; a significant reduction of the vessel diameter in Enterolobium; a significant reduction in the ray width of Cedrelinga; and a significant increase in ray width of Enterolobium can be explained by the quantity of axial parenchyma cells and thickness of the fiber walls (Muñiz et al. 2012).

Dimensional variations are related to tangential contraction in volume (Vale et al. 2010). Although the carbonization temperature did not substantially modify the basic structure, there was a reduction of the wall thickness of the axial parenchyma cells and contraction of the mechanical tissues (Lopez Pasquali et al. 2002). According to the authors cited above, the fact that the basic original structure is maintained in the solid residues can be attributed mainly to the residual lignin, which is the structural component of wood that degrades the slowest.

The characteristics of the carbonized wood of the species studied here are comparable with the descriptions of noncarbonized wood of these species, without identification of age and origin, found in Richter and Dallwitz (2000), Alves and Angyalossy-Alfonso (2002) and León and Williams (2006). Based on this information, the anatomical structure of the wood samples after carbonization can be used to enable identifying the species.

The charcoal contents of volatiles and ash obtained in the studied species are greater than those of the different eucalyptus species and clones normally used to make charcoal for the steel industry (Oliveira et al. 2010; Santos et al. 2011; Neves et al. 2011) and similar to those of some native species (Silva et al. 2007; Protásio et al. 2011). The levels of fixed carbon and calorific power are lower than those of eucalyptus species and clones (Oliveira et al. 2010; Neves et al. 2011; Santos et al. 2011) and similar to those of other species from cerrado regions and the Amazon Forest (Vale et al. 2001; Silva et al. 2007; Protásio et al. 2011).

According to Vale et al. (2001), the higher the content of fixed carbon and the lower the levels of volatiles and ash, the greater the calorific power of the wood or charcoal will be. For Schefflera macrocarpa, the authors found $77.4 \%$ fixed carbon; $21.5 \%$ volatile material; $1.05 \%$ ash; and $7,741 \mathrm{kcal} \mathrm{kg}^{-1}$ of upper calorific power. They also observed a weak correlation between basic wood density and charcoal quality of the 12 cerrado species studied, so they did not recommend using 
Table 2. Charcoal properties.

\begin{tabular}{lccccc}
\hline Species & Moisture $(\%)$ & $\begin{array}{c}\text { Calorific Power } \\
\left(\mathrm{kJ} \mathrm{kg}^{-1}\right)\end{array}$ & $\begin{array}{c}\text { Volatiles Compounds } \\
(\%)\end{array}$ & $\begin{array}{c}\text { Ash } \\
(\%)\end{array}$ & $\begin{array}{c}\text { Carbon } \\
(\%)\end{array}$ \\
\hline Byrsonima spicata & 4.4 & 27,705 & 27.9 & 1.3 & 70.8 \\
Calophyllum brasiliense & 3.1 & 28,657 & 31.7 & 0.1 & 68.2 \\
Cecropia sciadophylla & 4.2 & 29,212 & 20.9 & 3.8 & 75.3 \\
Cochlospermum orinocense & 4.6 & 26,878 & 24.2 & 3.4 & 72.5 \\
Schefflera morototoni & 4.5 & 31,117 & 22.6 & 2.0 & 75.3 \\
\hline
\end{tabular}

basic density to estimate those variables. A study of the quality of charcoal made from two cerrado species against that made from Eucalyptus grandis concluded that the cerrado species carbonized individually were better for production of charcoal than eucalyptus, and that the two cerrado species had similar quality (Vale et al. 1996).

Studies have demonstrated that charcoal for making pig iron and steel should have fixed carbon content above 75\%, since this content is directly responsible for the specific consumption of the reducer (carbon) and consequently for the production of pig iron. The ash content should be as low as possible, since high levels can cause accumulation of impurities inside solidified metal, causing variations in the physical, chemical and mechanical properties of pig iron (Neves et al. 2011).

According to the current regulations issued by the São Paulo state government, which require volatiles content lower than $23.5 \%$ for charcoal for household use, only charcoal from the species Cecropia and Schefflera is acceptable. On the basis of the ash content threshold (lower than 1.5\%), Calophyllum and Byrsonima can be used. In relation to the fixed carbon level, none of the species would be acceptable for either household use (Rosa et al. 2012) or for iron and steel making (Neves et al. 2011).

\section{CONCLUSION}

Anatomical structures of charcoal can be applied for species identification. The different dimensional changes between the species are the result of the variation of the fiber wall thickness and the arrangement of the axial parenchyma cells. The studied species are not indicated for charcoal production because the level of ash and volatiles are higher than those allowed for charcoal for household use and the calorific power and level of fixed carbon are insufficient for use in the steel industry.

\section{ACKNOWLEDGMENTS}

The authors thanks to Guavira Industrial e Agroflorestal for wood samples, Laboratório de Anatomia e Qualidade da Madeira (LANAQM) from Universidade Federal do Paraná for anatomical analysis and CNPF - Embrapa Florestas for charcoal analysis.

\section{REFERENCES}

Alves, E.S.; Angyalossy-Alfonso, V. 2002. Ecological trends in the wood anatomy of some Brazilian species. 2. Axial parenchyma, rays and fibres. Iawa Journal, 23: 391-418.

Associação Brasileira de Normas Técnicas. 1983. ABNT NBR 8112: Carvão vegetal - Análise imediata. Rio de Janeiro, 5 p.

Associação Brasileira de Normas Técnicas. 1984. ABNT NBR 8633: Carvão vegetal - Determinação do poder calorifico - método de ensaio. Rio de Janeiro, 13 p.

Gonçalves T.A.P.; Marcati, C.R.; Scheel-Ybert, R. 2012. The effect of carbonization on wood structure of Dalbergia violaceae, Stryphnodendron polyphyllum, Tapirira guianensis, Vochysia tucanorum and Pouteria torta from the Brazilian cerrado. IAWA Journal, 33: 73-90.

IAWA. 1989. List of microscopic features for hardwood identification. IAWA Bulletin, 10: 219-332.

Kim, N.H.; Hanna, R.B. 2006. Morphological characteristics of Quercus variabilis charcoal prepared at different temperatures. Wood Science and Technology, 40: 392-401.

Kwon, S.M.; Kim, N.H.; Cha, D.S. 2009. An investigation on the transition characteristics of the wood cell walls during carbonization. Wood Science and Technology, 43: 487-498.

León, H.; Williams, J. 2006. Anatomía de la madera de 17 especies de la familia Malpighiaceae Juss. Acta Cientifica Venezoelana, 57: 49-58

López Pasquali, E.E.; Wottitz, C.A.; Martinez, R.G.; Herrera, H.A. 2002. Carbonization of "algarrobo negro" (Prosopis nigra): a study of its microstructure and main volatile components. Latin American Applied Research, 32: 321-325.

Moreira, J.M.M.A.P. 2011. Potencial e participação das florestas na matriz energética. Pesquisa Florestal Brasileira, 31: 363-372.

Muñiz, G.I.B.; Nisgoski, S.; França, R.F.; Schardosin, F.Z. 2012. Anatomia comparativa da madeira e carvão de Cedrelinga catenaeformis Ducke e Enterolobium schomburgkii Benth. para fins de identificação. Scientia Forestalis, 40: 291-297. 
Neves, T.A.; Protásio, T.P.; Couto, A.M.; Trugilho, P.F.; Silva, V.O.; Vieira, C.M.M. 2011. Avaliaçáo de clones de Eucalyptus em diferentes locais visando à produção de carvão vegetal. Pesquisa Florestal Brasileira, 31: 319-330.

Oliveira, A.F.G. 2008. Testes estatísticos para comparação de médias. Revista Eletrônica Nutritime, 5: 777-788.

Oliveira, A.C.; Carneiro, A.C.O.; Vital, B.R.; Almeida, W.; Pereira, B.L.C.; Cardoso, M.T. 2010. Parâmetros de qualidade da madeira e do carvão vegetal de Eucalyptus pellita F. Muell. Scientia Forestalis, 38: 431-439.

Paula, J.E; Alves, J.L.H. 2007. 897 Madeiras nativas do Brasil: anatomia, dendrologia, dendrometria, produção, uso. Porto Alegre: Cinco Continentes. 438p.

Prior, J.; Gasson, P. 1993. Anatomical changes on six African hardwoods. IAWA Journal, 14: 77-86.

Protásio, T.P.; Santana, J.D.P.; Neto, R.M.G.; Júnior, J.B.G.; Trugilho, P.F.; Ribeiro, I.B. 2011. Avaliaçáo da qualidade do carvão vegetal de Qualea parviflora. Pesquisa Florestal Brasileira, 31: 295-307.

Richter, H. G.; Dallwitz, M. J. 2000. Commercial timbers: descriptions, illustrations, identification, and information retrieval. Version: 25th June 2009. (http://delta-intkey.com/ wood/index.htm). Accessed on 3/12/2012.

Rosa, R.A.; Arantes, M.D.C.; Paes, J.B.; Andrade, W.S.P.; Moulin, J.C. 2012. Qualidade do carváo vegetal para o consumo doméstico. Journal of Biotechnology and Biodiversity, 3: 41-48.
Santos, R.C.; Carneiro, A.C.O.; Castro, A.F.M.; Castro, R.V.O.; Bianche, J.J.; Souza, M.M.; Cardoso, M.T. 2011. Correlaçóes entre os parâmetros de qualidade da madeira e do carvão vegetal de clones de eucalipto. Scientia Forestalis, 39: 221-230.

Santos, S.F.O.M.; Hatakeyama, K. 2012. Processo sustentável de produção de carvão vegetal quanto aos aspectos: ambiental, econômico, social e cultural. Produção, 22: 309-321.

Silva, M.G.; Numazawa, S.; Araujo, M.M.; Nagaishi, T.Y.R.; Galvão, G.R. 2007. Carvão de resíduos de indústria madeireira de três espécies florestais exploradas no município de Paragominas, PA. Acta Amazonica, 37: 61-70.

Vale, A.T.; Nogueira, M.V.P.; Silva, M.A. 1996. Rendimento da carbonização e qualidade do carvão vegetal de madeiras do cerrado em comparação ao Eucalyptus grandis. Revista Árvore, 20: 93-99.

Vale, A.T.; Costa, A.F.; Gonçalvez, J.C.; Nogueira, M. 2001. Relaçóes entre a densidade básica da madeira, o rendimento e a qualidade do carvão vegetal de espécies do cerrado. Revista Árvore, 25: 89-95.

Vale, A.T.; Dias, I.S.; Santana, M.A.E. 2010. Relações entre propriedades químicas, físicas e energéticas da madeira de cinco espécies do cerrado. Ciência Florestal, 20: 137-145.

Yazdani, M.G.; Hamizan, M.; Shukur, M.N. 2012. Investigation of the fuel value and the environmental impact of selected wood samples gathere $\mathrm{d}$ from Brunei Darussalam. Renewable and Sustainable Energy Reviews, 16: 4965-4969.

Recebido em 09/09/2013

Aceito em 19/01/2014 